\title{
Key Concepts of ITF-1 \& ITF-2 toward Space Education and Outreach for the Benefit of All People
}

\author{
By Atsushi YASUDA, ${ }^{1)}$ Hiroki KAMEDA ${ }^{2)}$ and Toshihiro KAMEDA ${ }^{3)}$ \\ ${ }^{1)}$ College of Physics, School of Science and Engineering, University of Tsukuba, Tsukuba, Japan \\ ${ }^{2)}$ College of Engineering Systems, School of Science and Engineering, University of Tsukuba, Tsukuba, Japan \\ ${ }^{3)}$ Department of Engineering Mechanics \& Energy, Graduate School of Systems and Information Engineering, University of Tsukuba, Tsukuba, Japan
}

(Received July 30th, 2015)

\begin{abstract}
Since the effective satellite-based education and outreach methods has not been clarified so far, we researched satellites in the world and their activities in order to extract essential issues from the viewpoints of successful education and outreach. As the results, we found the following three key points are all required for successful space education and outreach with satellites; "No limit type": the satellite everyone can use, "Participation type": the satellite users can participate in its mission, and "Interaction type": the satellite users can interact each other. Furthermore, as the example to fulfill these key points, we introduce CubeSats, ITF-1 and ITF-2 developed by University of Tsukuba YUI Project, with their missions and activities related with space education and outreach.
\end{abstract}

Key Words: Satellite, Education, Outreach, Global mission design, Demand analysis

\section{Introduction}

Since the first artificial satellite Sputnik was launched in 1957, many satellites have been launched by various organizations around the world. In recent years, satellites have been developed not only by companies but also by university laboratories. In particular, CubeSats that have been developed by universities are used not only for scientific and technical missions but also for space education and outreach.

However, space education and outreach with CubeSats are not familiar to most people because effective methods are not well-established. There are no satellites mainly aimed toward space education or outreach so far.

As a unique attempt to improve this situation, we developed $I T F-1$ in YUI Project, which is a satellite development project of University of Tsukuba to connect people around the world through the construction of "YUI network." This mission is closely related to space education and international interaction. After ITF-1 was launched, we could not receive its signal, thus the main mission was not perfectly completed. At present, a second satellite called ITF-2 is being developed in order to further improve YUI network.

In this paper, we focus on a number of CubeSats with missions of space education and outreach. Based on this research, we present an analysis of effective outreach methods. We introduce $I T F-1$ as an example of this method and our second satellite $I T F-2$ with feedback to improve YUI network. Finally, we propose more effective activities to space education and outreach by satellites.

\section{Research}

In order to understand whether space education and outreach with CubeSats are familiar, we researched a number of satellite development groups. After that, we focused on the use of their satellites for space education and outreach, and the effects of each activity. This research was based on the following conditions.

(1) Only CubeSats developed by universities around the world were targeted. Satellites developed by military, countries, or companies were not targeted.

(2) We analyzed effective methods for space education and outreach with CubeSats developed by universities. Therefore, we did not ask for information about the satellites and activities from each group.

(3) In this paper, we define space education as educational activities carried out with a CubeSat for the public. Outreach is an activity to spread interest and concern about CubeSat missions and space educational activities. A group with space education and outreach provides educational activities and outreach with CubeSats. We only focused on groups with educational activities and outreach using CubeSats.

In this research, we referred to Wikipedia ${ }^{1)}$ and UNISEC website. $^{2)}$ We researched 98 CubeSats. Fifteen satellite development groups used CubeSats to perform educational activities and outreach. These numbers do not include the satellite developed by YUI Project of University of Tsukuba. Table 1 presents the results of our research. 
Trans. JSASS Aerospace Tech. Japan Vol. 14, No. ists30 (2016)

Table 1. List of CubeSats and groups with space education and outreach.

\begin{tabular}{|c|c|c|}
\hline $\begin{array}{c}\text { Name } \\
\text { (Organization) }\end{array}$ & Mission & Space education and outreach \\
\hline \multirow[t]{2}{*}{$\begin{array}{l}{\left.\text { Negai } \iota^{\prime \prime 3}\right)}{ }^{\text {(Soka University) }}\end{array}$} & \multirow{2}{*}{$\begin{array}{l}\text { 1. To cheer children up by loading messages onto } \\
\text { the satellite gathered from the public } \\
\text { 2. To demonstrate that a satellite system controlled } \\
\text { by a field-programmable gate array (FPGA) is } \\
\text { resistant to cosmic radiation }\end{array}$} & $\begin{array}{l}\text { They gathered } 8000 \text { messages from the public where } \\
\text { the names of babies and dreams of children were } \\
\text { written. These messages were converted into } \\
\text { microfilms and loaded onto the satellite. }\end{array}$ \\
\hline & & $\begin{array}{l}\text { They held the observation event at the ground station of } \\
\text { their satellite in Hachijojima. }\end{array}$ \\
\hline $\begin{array}{c}\text { HORYU-II }{ }^{4)} \\
\text { (KIT(Kyusyu Institute of } \\
\text { Technology) satellite project) }\end{array}$ & $\begin{array}{l}\text { 1. To manage the program as a part of the systems } \\
\text { engineering educational program } \\
\text { 2. To complete the satellite by the launch of } \mathrm{H} 2 \mathrm{~A} \\
\text { rocket in } 2011 \text { winter season } \\
\text { 3. To demonstrate that satellite bus technology } \\
\text { operates normally in space } \\
\text { 4. To generate } 300 \mathrm{~V} \text { power on low orbit } \\
\text { 5. To provide regional contributions and personal } \\
\text { training program with camera photography } \\
\text { image }\end{array}$ & $\begin{array}{l}\text { They held the event where participants experienced } \\
\text { receiving a signal from the satellite with a handmade } \\
\text { antenna. About } 20 \text { people attended this event. }{ }^{5}\end{array}$ \\
\hline \multirow{2}{*}{$\begin{array}{l}\text { INVADER }^{6} \text { ) } \\
\text { (Tama Art University, } \\
\text { The University of Tokyo) }\end{array}$} & \multirow{2}{*}{$\begin{array}{l}\text { 1. To design artwork utilizing data received from } \\
\text { the satellite } \\
\text { 2. To develop an application programming } \\
\text { interface (API) to easily obtain and utilize data } \\
\text { from the satellite } \\
\text { 3. To develop works using the satellite as an } \\
\text { interactive medium } \\
\text { 4. To suggest new ways to utilize satellites through } \\
\text { art and design }\end{array}$} & $\begin{array}{l}\text { At the exhibition "Open Space } 2012 \text { ", they displayed } \\
\text { artwork utilizing data from the satellite. They also held } \\
\text { a talk show and symposium there.? }\end{array}$ \\
\hline & & $\begin{array}{l}\text { They took part in "Maker Faire Tokyo 2013" and } \\
\text { displayed models of their satellite. }{ }^{8)}\end{array}$ \\
\hline \multirow{4}{*}{$\begin{array}{l}\text { DESPATCH }^{9)} \\
\text { (Tama Art University, } \\
\text { The University of Tokyo) }\end{array}$} & \multirow{4}{*}{$\begin{array}{l}\text { 1. To design and fabricate a "deep space sculpture" } \\
\text { 2. To compose and encode poetry that reflects not } \\
\text { only the sensor data but also the artist's } \\
\text { subconscious personality a kind of } \\
\text { "tele-creation" process "cooperative diversity } \\
\text { 3. To experiment "coms "o which is a system comprising } \\
\text { communications," which } \\
\text { ground stations around the world receiving weak } \\
\text { signals from deep space and recombining the } \\
\text { data with the Web and social networks } \\
\text { 4. To perform onboard verification of 3D-printed } \\
\text { parts of space instruments }\end{array}$} & $\begin{array}{l}\text { They held a talk show at the National Museum of } \\
\text { Emerging Science and Innovation. }{ }^{10)}\end{array}$ \\
\hline & & $\begin{array}{l}\text { They held lectures at the event "Matsudo Scientist } \\
\text { Night5."11) }\end{array}$ \\
\hline & & $\begin{array}{l}\text { They took part in "Maker Faire Tokyo 2014" and } \\
\text { displayed models of their satellite. They also gave a } \\
\text { presentation about their satellite there. } \text {. }^{12,13)}\end{array}$ \\
\hline & & $\begin{array}{l}\text { They made a short film about their satellite and showed } \\
\text { it at a city museum in Sagamihara. }{ }^{14)}\end{array}$ \\
\hline \multirow{2}{*}{$\begin{array}{l}\text { STARS }^{15)} \\
\text { (Kagawa University) }\end{array}$} & \multirow{2}{*}{$\begin{array}{l}\text { 1. To deploy and retrieve tether of short range } \\
\text { 2. To control daughter satellite } \\
\text { 3. To take photos each other } \\
\text { 4. To communicate between satellites }\end{array}$} & $\begin{array}{l}\text { They taught children about satellite mechanisms } \\
\text { through an easy experiment at their open campus and } \\
\text { festival at Kagawa University ( } 1600 \text { people participated } \\
\text { in this festival). }{ }^{16,17)}\end{array}$ \\
\hline & & $\begin{array}{l}\text { They requested } 24 \text { astronomical observatories to } \\
\text { observe their satellites STARS and STARS-II. } \text {. }^{8,19)}\end{array}$ \\
\hline
\end{tabular}




\begin{tabular}{|c|c|c|}
\hline \multirow{2}{*}{$\begin{array}{l}\text { STARS-II }{ }^{20)} \\
\text { (Kagawa University) }\end{array}$} & \multirow{2}{*}{$\begin{array}{l}\text { 1. To deploy Electro Dynamic Tether (EDT) by } \\
\text { gravity gradient } \\
\text { 2. To gather electrical current by EDT } \\
\text { 3. To control attitude by arm link motion based on } \\
\text { tether tension due to gravity gradient } \\
\text { 4. To deploy and retrieve tether by tether tension } \\
\text { control }\end{array}$} & $\begin{array}{l}\text { They taught children about satellite mechanisms } \\
\text { through an easy experiment at their open campus and } \\
\text { festival at Kagawa University ( } 1600 \text { people participated } \\
\text { in this festival). }{ }^{16,17)}\end{array}$ \\
\hline & & $\begin{array}{l}\text { They requested } 24 \text { astronomical observatories to } \\
\text { observe STARS-II. }{ }^{88,19)}\end{array}$ \\
\hline \multirow{4}{*}{$\begin{array}{l}\text { TeikyoSat-3 }{ }^{21)} \\
\text { (Teikyo University) }\end{array}$} & \multirow{4}{*}{$\begin{array}{l}\text { To load slime bacteria and examine the effects of a } \\
\text { microgravity environment and cosmic radiation on } \\
\text { them }\end{array}$} & $\begin{array}{l}\text { They held a debriefing session about their activities at } \\
\text { the culture center in Tochigi for about } 100 \\
\text { participants. }\end{array}$ \\
\hline & & $\begin{array}{l}\text { They participated in the scientific event "Enjoy! } \\
\text { Kagaku!!" at Teikyo University and explained their } \\
\text { satellite. }{ }^{23)}\end{array}$ \\
\hline & & $\begin{array}{l}\text { They presented about their activities at the aerospace } \\
\text { symposium in Tochigi. }{ }^{24)}\end{array}$ \\
\hline & & $\begin{array}{l}\text { They gave the open lecture about their activities at } \\
\text { Teikyo University. }{ }^{25} \text {. }\end{array}$ \\
\hline \multirow{3}{*}{$\begin{array}{l}\text { UNIFORM-126) } \\
\text { (Wakayama University } \\
\text { (Representative group)) }\end{array}$} & \multirow{3}{*}{$\begin{array}{l}\text { 1. To picture and detect thermal anomalies on } \\
\text { Earth for the purpose of detecting wildfires } \\
\text { 2. To realize capacity building development } \\
\text { through cooperation with other countries }\end{array}$} & $\begin{array}{l}\text { They held the small lecture meeting and explained their } \\
\text { activities at Wakayama University. }{ }^{27)}\end{array}$ \\
\hline & & $\begin{array}{l}\text { They held a public viewing for the launch of the } \\
\text { satellite. About } 300 \text { people participated. }{ }^{28)}\end{array}$ \\
\hline & & $\begin{array}{l}\text { They held events to explain their activities in Kishiwada } \\
\text { City. }{ }^{29)}\end{array}$ \\
\hline \multirow{2}{*}{$\begin{array}{c}\text { XI-IV }{ }^{30)} \\
\text { (The University of Tokyo) }\end{array}$} & \multirow{2}{*}{$\begin{array}{l}\text { 1. To gather satellite health information via a } \\
\text { beacon signal } \\
\text { 2. To uplink commands and downlink data } \\
\text { 3. To provide a telemetry data broadcasting service } \\
\text { 4. To verify the commercial-off-the-shelf (COTS) } \\
\text { components on orbit }\end{array}$} & $\begin{array}{l}\text { They distributed digital images of the Earth from their } \\
\text { satellite to the public through PCs and cellphone. About } \\
3000 \text { people registered with this service. }{ }^{31)}\end{array}$ \\
\hline & & $\begin{array}{l}\text { They gathered messages from about } 200 \text { people, } \\
\text { converted them into microfilms, and loaded them onto } \\
\text { the satellite. }{ }^{32,33)}\end{array}$ \\
\hline \multirow[b]{2}{*}{ (The University of Tokyo) } & \multirow{2}{*}{$\begin{array}{l}\text { 1. To demonstrate imaging technology by using an } \\
\text { "extensible boom" as a telescope } \\
\text { 2. To demonstrate COTS-oriented components for } \\
\text { nanosatellites } \\
\text { 3. To provide advanced amateur radio services so } \\
\text { that radio amateurs around the world can uplink, } \\
\text { record, and downlink messages using the } \\
\text { satellite }\end{array}$} & $\begin{array}{l}\text { They participated in the aerospace exhibition at Nagoya } \\
\text { and displayed an engineering model of their satellite. }\end{array}$ \\
\hline & & They provided the advanced amateur radio services. ${ }^{36)}$ \\
\hline
\end{tabular}




\begin{tabular}{|c|c|c|}
\hline \multirow{4}{*}{$\begin{array}{l}\text { HIT-SAT }^{37)} \\
\text { (HITSAT project of the } \\
\text { Hokkaido Institute of } \\
\text { Technology (at present, } \\
\text { Hokkaido University of } \\
\text { Science)) }\end{array}$} & \multirow{4}{*}{$\begin{array}{l}\text { 1. To experiment with the attitude control system } \\
\text { 2. To evaluate the thermal design of a satellite on } \\
\text { orbit } \\
\text { 3. To test functions of the mechanism to separate } \\
\text { the satellite from the rocket } \\
\text { 4. To acquire fundamental data of the satellite } \\
\text { 5. To examine the degradation of a satellite on } \\
\text { orbit that accompanies the operating cycle of the } \\
\text { power supply system }\end{array}$} & $\begin{array}{l}\text { They introduced the ground station to about } 40 \text { students } \\
\text { from Hokkaido Iwamizawa Ryokuryo High School. }{ }^{38)}\end{array}$ \\
\hline & & $\begin{array}{l}\text { They displayed an exhibition booth about their satellite } \\
\text { at Sapporo Science Center in Hokkaido. }{ }^{38)}\end{array}$ \\
\hline & & $\begin{array}{l}\text { They held a lecture meeting memorializing the launch } \\
\text { of their satellite at the campus festival of the Hokkaido } \\
\text { Institute of Technology. }{ }^{38)}\end{array}$ \\
\hline & & $\begin{array}{l}\text { They displayed an engineering model of their satellite } \\
\text { in an exhibition under the auspices of the Hokkaido } \\
\text { Aerospace Science and Technology Incubation } \\
\text { Center. }{ }^{38)}\end{array}$ \\
\hline \multirow{2}{*}{$\begin{array}{c}\text { SEEDS II }{ }^{39)} \\
\text { (Nihon University) }\end{array}$} & \multirow{2}{*}{$\begin{array}{l}\text { 1. To make satellite bus technology operate } \\
\text { normally and downlink data in Morse code } \\
\text { 2. To maintain data of the satellite state by using } \\
\text { gyro, magnetometric, and temperature sensors } \\
\text { and downlinking data for amateur packet } \\
\text { transfer communication } \\
\text { 3. To perform thermal analysis and analysis of the } \\
\text { satellite attitude using the received data } \\
\text { 4. To downlink the voice data that has been } \\
\text { recorded before the launch and downlink the } \\
\text { data and have people around the world listen to } \\
\text { the voice from space by using amateur radio }\end{array}$} & $\begin{array}{l}\text { They gathered about } 800 \text { messages from the public, } \\
\text { converted these messages into microfilms, and loaded } \\
\text { them onto the satellite. }{ }^{40)}\end{array}$ \\
\hline & & $\begin{array}{l}\text { They held three events, where participants were able to } \\
\text { experience receiving a signal from the CubeSat with a } \\
\text { handmade antenna.5) }\end{array}$ \\
\hline \multirow{4}{*}{$\begin{array}{l}{\text { Masat- }{ }^{41)}} \\
\text { (Budapest University of } \\
\text { Technology and Economics) }\end{array}$} & \multirow{4}{*}{$\begin{array}{l}\text { 1. To build and test a satellite which can survive } \\
\text { the launch process and the environment in space } \\
\text { as a basic success criteria } \\
\text { 2. To deliver a fully tested satellite to the launch } \\
\text { site and get a successfully released acknowl- } \\
\text { edgement from the launch vehicle } \\
\text { 3. To operate the Ground Station reliably } 24 / 7 \\
\text { 4. To receive telemetry packets from the satellite } \\
\text { 5. To control the satellite operation modes via } \\
\text { telecommands } \\
\text { 6. To correct and reliable operation of all satellite } \\
\text { subsystem } \\
\text { 7. To receive all scientific data and telemetry of the } \\
\text { satellite }\end{array}$} & $\begin{array}{l}\text { They held the exhibition at Corvin Plaza. They } \\
\text { displayed a model of their satellite. }{ }^{42)}\end{array}$ \\
\hline & & $\begin{array}{l}\text { They held the exhibition at National Instruments } \\
\text { Debrecen and explained their activities. }{ }^{43)}\end{array}$ \\
\hline & & $\begin{array}{l}\text { They gave the presentation about their activities to the } \\
\text { public at European Space Expo. }{ }^{44)}\end{array}$ \\
\hline & & $\begin{array}{l}\text { They displayed the mockup of their satellite at the } \\
\text { Hungarian National Museum and explained their } \\
\text { activities. }{ }^{45)}\end{array}$ \\
\hline \multirow{4}{*}{$\begin{array}{l}\quad \text { ShindaiSat }^{46)} \\
\text { (Shinshu University) }\end{array}$} & \multirow{4}{*}{$\begin{array}{l}\text { 1. To uplink data from the ground to their satellite } \\
\text { through visible light communications using } \\
\text { LED light } \\
\text { 2. To downlink data from the satellite to the } \\
\text { ground through visible light communications } \\
\text { using LED light }\end{array}$} & $\begin{array}{l}\text { They determined the satellite's name from } 4000 \\
\text { votes. }{ }^{47)}\end{array}$ \\
\hline & & $\begin{array}{l}\text { At Sakae Village Primary School in Nagano, they held } \\
\text { the event to observe the LED light from the satellite. } \\
\text { They also taught lessons about space debris and so } \\
\text { on. }{ }^{48)}\end{array}$ \\
\hline & & $\begin{array}{l}\text { They held the event to observe the LED light from the } \\
\text { satellite. }{ }^{48)}\end{array}$ \\
\hline & & $\begin{array}{l}\text { They requested several astronomical observatories to } \\
\text { observe the LED light from the satellite. }{ }^{47)}\end{array}$ \\
\hline \multirow{2}{*}{$\begin{array}{l}\quad \text { SPROUT }^{49)} \\
\text { (Nihon University) }\end{array}$} & \multirow{2}{*}{$\begin{array}{l}\text { 1. To verify the design methods and demonstrated } \\
\text { the deployment of an inflatable membrane } \\
\text { structure in space } \\
\text { 2. To demonstrate the attitude determination and } \\
\text { control technology of the satellite } \\
\text { 3. To predict the change in the orbit descent rate } \\
\text { with the inflatable membrane structure } \\
\text { 4. To have ham radio operators operate the satellite } \\
\text { 5. To perform local exchange activities }\end{array}$} & $\begin{array}{l}\text { They gathered about } 120 \text { messages from the public, } \\
\text { converted these messages into microfilms, and loaded } \\
\text { them onto the satellite. }{ }^{50)}\end{array}$ \\
\hline & & $\begin{array}{l}\text { They held the event in Chiba where about } 20 \\
\text { participants experienced receiving a signal from the } \\
\text { satellite with a handmade antenna. }{ }^{51)}\end{array}$ \\
\hline
\end{tabular}




\subsection{Analysis of data}

2.1.1. Spread of space education and outreach with CubeSats

The number of satellite development groups that used CubeSats for space education and outreach was about $15 \%$ of the number of groups we researched. This shows that the use of CubeSats for space education and outreach is not familiar. Many CubeSats have scientific and technical missions. However, some CubeSats have non-scientific missions such as Soka University's Negai ş", and Tama Art University and The University of Tokyo's ARTSAT. CubeSats are primarily developed as educational tools for students at universities or laboratories. In addition, CubeSats are smaller, cheaper, and have shorter development periods than large satellites. They are expected to also be useful for business. Therefore, many CubeSats have scientific and technical missions, and their use for space education and outreach is not familiar.

\subsubsection{Space education and outreach with CubeSat}

- Invitation for messages and nicknames

Some satellite development groups collected messages to load onto their CubeSat from their public or nicknames for their CubeSats, such as XI-IV of The University of Tokyo, SEEDS II and SPROUT of Nihon University, Negai $\overrightarrow{\text { « }}$ " of Soka University, and ShindaiSat of Shinshu University. Especially, Soka University collected approximately 8000 messages, and Shinshu University collected approximately 4000 nicknames. This shows that they spread interest and concern about CubeSats to many people and that their activities may provide effective outreach with CubeSats.

\section{- Cooperation to receive signals from CubeSat}

Each group and laboratory provided a format to report the reception of the signal from the CubeSat and data analysis software on their HP. Some groups, such as Kyushu Institute of Technology's HORYU-II and Nihon University's SEEDS II, held events so that ham operators and ordinary people experienced receiving the signal. In each event, people actually received the signal from the CubeSat with a handmade Yagi antenna for primary and junior high school students. For Nihon University's SPROUT, about 20 people including primary school students gathered at the event to receive a signal and listened to the voice from SPROUT. For Shinshu University's ShindaiSat, the satellite emitted lights from LEDs, and people on the ground could visually observe Morse code. The development team held an event so that primary school students could see it.

There were also satellites whose signals were impossible to be received without special equipment, such as DESPATCH of Tama Art University and The University of Tokyo.

The use of amateur radio needs a certain level of expertise about amateur radio and special equipment for the radio. For some people who lack experience or knowledge about amateur radio, using amateur radio with a CubeSat seems difficult. If we can provide a simple methods to receive signals from a CubeSat through the event such that children can participate easily with handmade antennas, this may effectively remove hesitation over receiving signals caused by the lack of amateur radio equipment and knowledge about its operation.

\section{General Viewpoint about Effective Outreach Methods}

From our research and analysis, we found a general viewpoint about effective outreach methods with CubeSats. We give it below.

- No limit type

Some CubeSats require special equipment and knowledge to communicate with them. Engineers or ham operators can communicate with them easily. However, ordinary people find it difficult to do so. Therefore, limiting space education and outreach to people who can use a CubeSat is not effective. We suggest that effective space education and outreach should allow easy communication with a CubeSat regardless of the age, knowledge and equipment of the user.

\section{- Participation type}

Effective space education and outreach should let people who are not affiliated with the CubeSat in general to participate in activities related to the satellite. Such activities should raise their interest and concern for science and technology. Useful examples include Negai $\varsigma^{\prime \prime}$ ", ShindaiSat, and the ham radio service of PRISM from The University of Tokyo.

\section{- Interaction type}

Some groups with outreach held a lecture or event receiving a signal from the satellite. The participants in the event can interact with each other at the location. However, it is hard for them to interact with other people who receive the signal at a different place. However, a ham operator can interact with other people around the world in real time with amateur radio.

If we promote interaction between people who have experience with receiving signals, it will effectively increase their pleasure, interest, and concern to interact with people who are not connected with each other. 


\section{Satellite Developed by YUI Project of University of Tsukuba}

In the previous section, we presented effective outreach methods with a CubeSat. In this section, we introduce the satellite developed by YUI Project of University of Tsukuba. This satellite is an example used to practice the above methods.

\subsection{Nanosatellite ITF-1}

ITF-1 is a CubeSat and the size of $1 \mathrm{U}: 10 \mathrm{~cm} \times 10 \mathrm{~cm} \times 10$ $\mathrm{cm}$ (Fig. 1). It was launched from Tanegashima Space Center on February 28, 2014, as a piggyback satellite. It reentered the atmosphere on June 29, 2014.

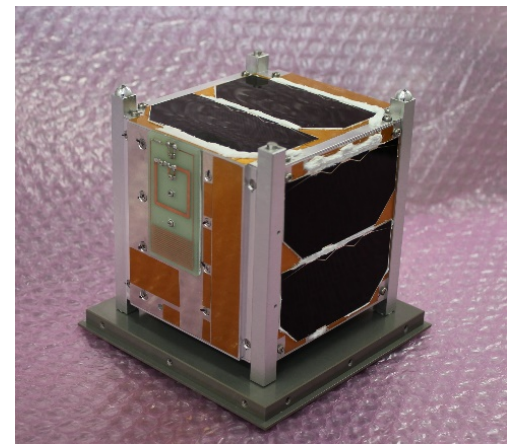

Fig. 1. ITF-1.

ITF-1 had three missions. The main mission of constructing YUI network should help with space education, international interaction and the spread of amateur radio (Fig. 2). YUI network connects people who experience receiving the signal from ITF-1 directly. Through the common experience of receiving the signal from the satellite, people who do not have a chance to meet in general can interact on the Internet. ITF-1 transmitted the satellite information by FM radio. We raised interest in receiving information from $I T F-1$ that changed with each moment by people around the world with YUI network. This should increase their interest in science and space. People could report the reception to a website managed by YUI Project. We provided people who reported receiving the ITF-1 signal the opportunity to interact on the Internet.
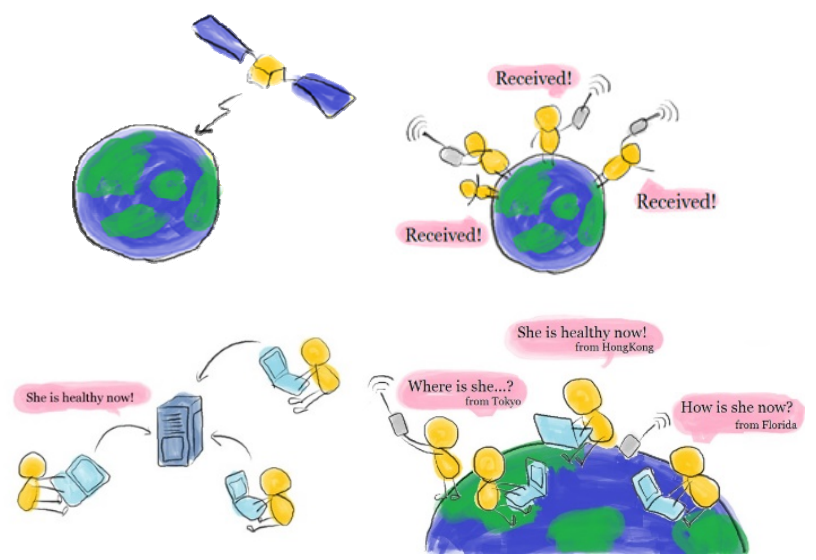

Fig. 2. Construction of "YUI" network.
ITF-1 uses amateur radio communication. Our aim was for people all over the world, including children, to be able to receive its signal easily without special equipment and knowledge. Therefore, we provided receivers to primary school students, who could also use a smartphone application to report reception. YUI network follows the concept of constructing of a network with a satellite that anyone participate in at any time by easy signal reception.

\subsubsection{Prospective effects of YUI network}

YUI network allows anyone to receive the ITF- 1 signal without limits on the age, country, and area. It is a global network and uses amateur radio communication. It is expected to improve the interaction between ordinary people and ham operators. Therefore, it should be effective for space education, international exchanges, and the spread of amateur radio.

\subsubsection{Activities of ITF-1}

We carried out various activities in order to construct YUI network. Figure 3 shows the handmade antenna made from corrugated board and wire to simplify reception. Figure 4 shows the smartphone application for easy reporting. As outreach activity, we announced information from HP and existing SNSs such as Twitter and Facebook. Figure 5 shows that we held an event to let primary school children make a simple handmade antenna. In addition, we introduced satellite and amateur radios at the event. As outreach for ham operators, we established the memorial radio station 8 N1ITF with the University of Tsukuba amateur radio club.

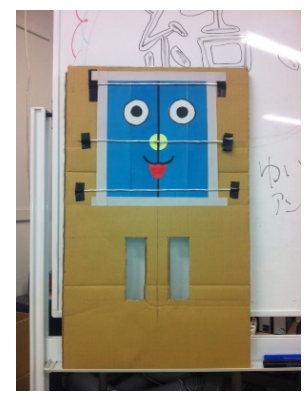

Fig. 3. Simple handmade antenna.

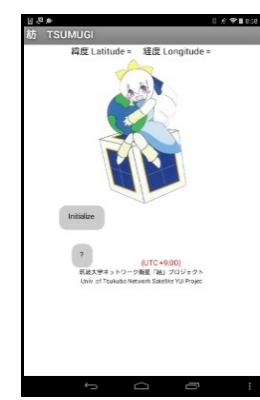

Fig. 4. Application for signal reception report. 


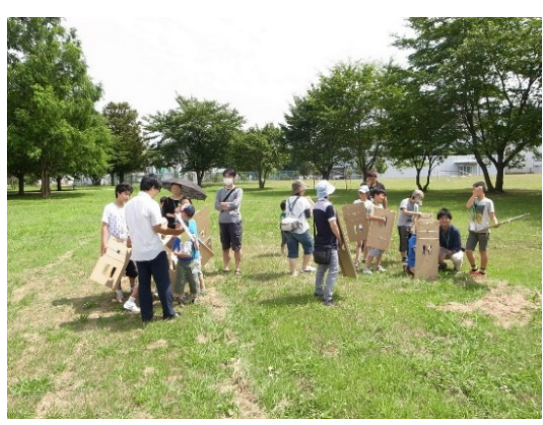

Fig. 5. Event for making antenna.

\subsection{Second satellite ITF-2}

After ITF-1 was developed, we began developing the second satellite $I T F-2$. The purpose of $I T F-2$ is to take over $I T F-1$ 's missions and further improve YUI network. ITF-1 transmitted Morse code in F2A. With $I T F-2$, our aim is to downlink voice and picture data to facilitate intuitive understanding of the signal and attract people to participate in YUI network. In order to improve outreach, we will announce information from HP, Twitter, and Facebook in English, distribute video to show how to make handmade antennas, and hold events to teach how to make antennas. We will diligently provide information on YUI network. We need to construct YUI network in the development phase. Therefore, we established a mission promotion team that is in charge of preparing for YUI network.

\section{Conclusion}

By studying past launched satellites related to education and outreach, we found the following three key points are all required for successful space education and outreach with satellites; "No limit type": the satellite everyone can use, "Participation type": the satellite users can participate in its mission, and "Interaction type": the satellite users can interact each other. Furthermore, we introduce ITF-1 and ITF-2 developed by University of Tsukuba YUI Project, as the specific examples.

\section{References}

1) List of CubeSats in Wikipedia, 2015, http://en.wikipedia.org/wiki/List_of_CubeSats (in Japanese) (accessed 18 February 2015)

2) UNISEC website, http://www.unisec.jp/about/satellite.html (in Japanese) (accessed 18 February 2015)

3) Yoshiga, H., and Kuroki, S.: The operative result report of nanosatellite "Negai ${ }^{2}$ " in Soka University, http://www.unisec.jp/history/g-a/2010/03.pdf (in Japanese)

4) $100^{\text {th }}$ Anniversary SAT HORYU KIT Satellite Project, http://kitsat.ele.kyutech.ac.jp/FormerPage_horyu2_top.html (in Japanese)
5) Nakamoto, M.: The first report of GNS outreach/Space Club, Kyushu Institute of Technology, 2012, available at http://www.unisec.jp/unison/event/2011/111113.pdf (in Japanese)

6) ARTSAT website, http://artsat.jp/project/invader (in Japanese)

7) ICC ONLINE website, http://www.ntticc.or.jp/Archive/2012/Openspace2012/Works/artsat j.html (in Japanese)

8) Maker Faire Tokyo 2013 website, http://makezine.jp/event/mft2013/program/ (in Japanese)

9) ARTSAT website, http://artsat.jp/en/project/despatch (in Japanese)

10) Miraikan website, http://www.miraikan.jst.go.jp/event/1411111817561.html (in Japanese)

11) Peatix website, http://peatix.com/event/66522 (in Japanese)

12) SHUASU PLUS website, http://weekly.ascii.jp/elem/000/000/182/182624/ (in Japanese)

13) Maker Faire Tokyo 2014 website, http://makezine.jp/event/mft2014/program/presentation/ (in Japanese)

14) Sagamihara City Museum website, http://sagamiharacitymuseum.jp/plane/planetarium/ (in Japanese)

15) STARS Project website, http://stars.eng.shizuoka.ac.jp/english/about_kukai.html

16) Neya, K.: Motto Shiritai Jinkōeisei!, Kagawa University http://www.kagawa-u.ac.jp/files/3913/9643/6316/08\%20eisei.pdf (in Japanese)

17) Kagawa Gennai Network website, http://imd.eng.kagawa-u.ac.jp/gennai/ (in Japanese)

18) STARS Project website, http://stars.eng.shizuoka.ac.jp/for_astro/photo.html (in Japanese)

19) STARS Project website, http://stars.eng.shizuoka.ac.jp/for_astro/kyouryoku.html (in Japanese)

20) STARS Project website, http://stars.eng.shizuoka.ac.jp/english/STARS-II_summary.html

21) TeikyoSat website, http://club.uccl.teikyo-u.ac.jp/ space_system_society/teikyosat-3.h tml (in Japanese)

22) Uchu System Kenkyukai website, http://spacesystem.blog.fc2.com/ (in Japanese)

23) Uchu System Kenkyukai website, http://spacesystem.blog.fc2.com/blog-entry-35.html (in Japanese)

24) Teikyo University website, http://www.teikyo-u.ac.jp/campus_news/utsunomiya/2013/0812_3 180.html (in Japanese)

25) Teikyo University website, https:/www.teikyo-u.ac.jp/contribution/regional/itabashi_campus/o pen_lectures/2014/0210_3448.html (in Japanese)

26) Mission Outline of No.24 H-IIA rocket, Mitsubishi Heavy Industries,Ltd., JAXA, 2014 http://www.mext.go.jp/b_menu/shingi/gijyutu/gijyutu2/059/shiryo/ _icsFiles/afieldfile/2014/08/04/1343661_13.pdf (in Japanese)

27) Wakayama University website, http://www.wakayama-u.ac.jp/tourism/cafe-s20140626.html (in Japanese) 
28) Wakayama Keizai Shimbun website, http://wakayama.keizai.biz/headline/152/ (in Japanese)

29) Wakayama University website, http://www.wakayama-u.ac.jp/kishiwada/pickup/pickup_37.html (in Japanese)

30) The University of Tokyo CubeSat Project website, http://www.space.t.u-tokyo.ac.jp/cubesat/mission/abst/index-e.html

31) Earth Image Data Distribution Service, http://www8.cao.go.jp/space/seminar/fy26-dai1/nakasuka-2.pdf (in Japanese)

32) Kawashima, R.: CubeSat Monogatari, 2005, pp. 150-152 (in Japanese)

33) The University of Tokyo CubeSat Project website, http://www.space.t.u-tokyo.ac.jp/cubesat/mission/message/ (in Japanese)

34) PRISM website, http://www.space.t.u-tokyo.ac.jp/prism/en/about.html

35) PRISM website, http://www.space.t.u-tokyo.ac.jp/prism/news.html (in Japanese)

36) PRISM website, http://www.space.t.u-tokyo.ac.jp/prism/HAMservice.html (in Japanese)

37) HIT-SAT Project website, http://www1.hus.ac.jp/ satori/hitsat/project/project.htm (in Japanese)

38) HIT-SAT Project website, http://www1.hus.ac.jp/ satori/hitsat/ (in Japanese)

39) Nihon University Report of Success in the Launch of No. 2 SEEDS, Nihon University, 2008, available at http://www.cst.nihon-u.ac.jp/news/SEEDS2.pdf (in Japanese)

40) Nihon University CubeSat Project Official Web site, http://cubesat.aero.cst.nihon-u.ac.jp/japanese/microfirm.html\#01 (in Japanese)

41) Masat-1 website, http://cubesat.bme.hu/en/projektek/masat-1/

42) Masat-1 website, http://cubesat.bme.hu/en/galeria/2013-10-12-masat-1-a-corvin-plaz aban/

43) Masat-1 website, http://cubesat.bme.hu/galeria/2013-09-01-national-instruments-deb recen-csaladi-nap/

44) Masat-1 website, http://cubesat.bme.hu/en/galeria/2013-03-23-masat-1-eloadas-a-eur opean-space-expo-n-budapest/

45) Masat-1 website, http://cubesat.bme.hu/en/galeria/2014-10-10

46) GINREI Project website, Shinshu University http://www.shinshu-u.ac.jp/faculty/engineering/chair/elec006/proje ct_mgaiyou.html (in Japanese)

47) Sekaihatsu! LED Kashikō Tsūshin Towa, 2012 http://www.shinshu-u.ac.jp/shindaisat/ (in Japanese)

48) Shinshu University website, http://www.shinshu-u.ac.jp/event/2014/10/10222528.html (in Japanese)

49) SPROUT website, http://sat.aero.cst.nihon-u.ac.jp/sprout-e/1-Mission-e.html

50) SPROUT website, http://sat.aero.cst.nihon-u.ac.jp/sprout/Microfilm/gallery.html (in Japanese)

51) SPROUT website, http://sat.aero.cst.nihon-u.ac.jp/sprout/3-Outreach\%20activities.ht $\mathrm{ml}$ (in Japanese) 